\title{
Coastal cities and cultural heritage: problems of conservation and management - the ancient walled city of Cagliari (Italy)
}

\author{
D. R. Fiorino \& S. M. Grillo \\ Department of Civil Environmental Engineering and \\ Architecture (DICAAR), University of Cagliari, Italy
}

\begin{abstract}
The present research investigates problems related to Mediterranean coastal cities with specific regards to stratified sites, characterized by a relevant cultural heritage associated with an outstanding landscape. This heritage is generally exposed to threats that are typical of coastal environment, such as damage by sea salts, wind erosion, corrosion from pollution, as well as anthropic risks such as urban development, pressure from tourism and vandalism. The case study of the city of Cagliari is particularly relevant in this context because of its strategic location in the heart of the Mediterranean. The relationship of the city towards the sea has changed over time, from being a defensive stronghold to becoming an international tourist centre, oriented towards the exploitation of its cultural heritage. This transformation was made by means of a wide expansion outside the walled perimeter and the construction of new hotels. New buildings were constructed using the same brightly coloured materials, following the tradition of the old town. Recently, even the historic town has discovered its touristic potential with the conversion of old residences into small hotels and bed and breakfast accommodation. Risks connected with human and touristic activities seem to be even more dangerous than the degradation caused by natural phenomena. For these reasons, the research highlights the importance, especially for coastal cities, of a multidisciplinary strategic plan and of an integrated tool for monument's preservation and for the monitoring of urban transformation.

Keywords: preservation, weathering, degradation, touristic pressure, monitoring.
\end{abstract}




\section{Introduction}

Mediterranean coastal cities are characterised by outstanding cultural heritage and landscapes. The relationship between old towns and the sea has always been different, since the sea has not only been a resource for coastal communities, but also a threat. In fact, several sea towns were founded as military strongholds with the express purpose of controlling the administrative boundaries. At the same time, every coastal settlement is characterized by the presence of a harbour and a market to manage commerce. Moreover, these military citadels are frequently stratified sites, where every layer is related to different foreign domination.

However, with recent military decommissioning, the defensive mission has turned into a tourist activity. This reconversion can be difficult, slow, dangerous or even harmful in terms of heritage protection. On the other hand, effective control of these changes can represent a unique opportunity of sustainable development for coastal municipalities.

This case study of Cagliari is particularly relevant in this context because of its strategic location in the heart of the Mediterranean, its long history, its natural and environmental peculiarities, its remarkable military heritage and its tourism. Starting from this example, the research investigates the historical relationship between the city and the sea. It recognizes new typologies of cultural sites related to their coastal mission; identifies the vulnerability of the coastal monuments; outlines the possible challenges for sustainable preservation and the respectful reuse of local heritage.

\section{The long history of the coastal city (DRF)}

Cagliari is Sardinia's main city. It is located in the Gulf of Angels, surrounded by lagoons. One of these lagoons, Molentargius, was recognized in 1977 by the Ramsar Convention as a site of international interest. Cagliari's natural and urban environment contains all the elements of a complex coastal city, with the old town and the urban expansions, the historic harbour and the new Container Harbour and a very long beach. It is surrounded by sixteen municipalities creating a conurbation of around 419,000 inhabitants (figure 1).
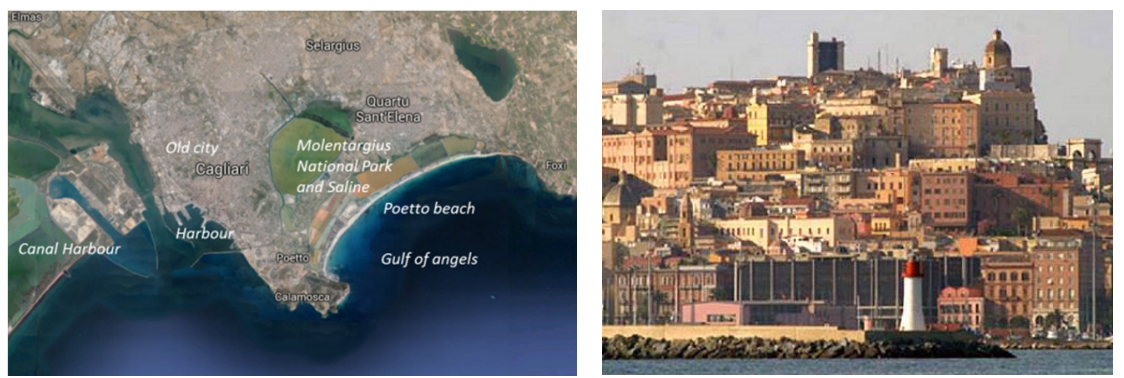

Figure 1: The coastal city of Cagliari in its bay. General map of the urban territory and a view of the old citadel from the sea. 
These natural resources and the strategic location in the Mediterranean were the cause of a long history of domination and consequent transformation of the built environment, so that the modern city is the extraordinary result of several mixed cultures and architectural styles. Ancient to modern buildings are characterised by the dominance of bright colours due to different stones and plasters used over time.

In the city, we can still find remains dating from Phoenician and Roman times, to Vandal (V century), Byzantine (VI century) and Arab (VIII century).

In Medieval times the settlement was located in the nearby marsh, called Santa Igia in the western lagoon, close to the current Container Harbour. It was the main town of the 'Giudicato di Cagliari', one of the four autonomous regions of Sardinia. In 1258 Benedetta di Massa, head of the Giudicato, gave the Pisans a hill where they built a well-fortified castle. This was the birth of a new Mediterranean military stronghold.

\subsection{The coastal military citadel}

The first Pisan settlement, the Castello quarter, was developed following the direction of the contour lines of the hill, with a central axis, the Ruga Mercatorum, oriented toward the city of Pisa. This main street connected two urban gates: the northern St. Pancrazio gate, also known as the Eagle gate, the southern Lion gate. The town itself has the shape of an Eagle, with a cross in the chest. The Pisan settlement was characterised by the typical gothic long and narrow allotments with 'slim' houses on them. Each house has a very narrow facade on the street, developed from one to three floors. The ground floors were often used as warehouses, artisan workshops or stables; the upper floors were residences.

The old coastal settlement was divided into four walled quarters and a dock. Stampace and Villanova lost their walls very early. Marina - the harbour quarter - lost them later while Castello still remains a fortified citadel.

From 1324 to 1720, the Spanish Crown (Aragona) dominated Cagliari and all of Sardinia. In this period several churches were built, but the most related to the sea is the Basilica of Our Lady of Bonaire, patron saint of sailors and seafarers (figure 2). At the top of a monumental staircase, the former sanctuary, built in 1324-1326, stands next to a pre-Roman and Roman necropolis. In the octagonal apse chapel is the wooden statue of Blessed Virgin of Bonaire presiding over the high altar. The sculpture was discovered by the Mercenary Fathers in a chest in a stretch of water just opposite to the church.

During the long Spanish period, many of the previous narrow houses were merged together by the rising middle class to become wider elegant palaces.

The transformation process was always the same: they typically bought two or three terraced houses and merged them, adding a monumental staircase in the middle and a prestigious gate in the facade on the main street. Sometimes, even windows were modified in dimension and shape, but maintaining their position for structural convenience.

In 1720 Sardinia was added to Savoy Kingdom in exchange for Sicily. Until 1866 Cagliari was mostly intended as a military site, so that the settlement has 


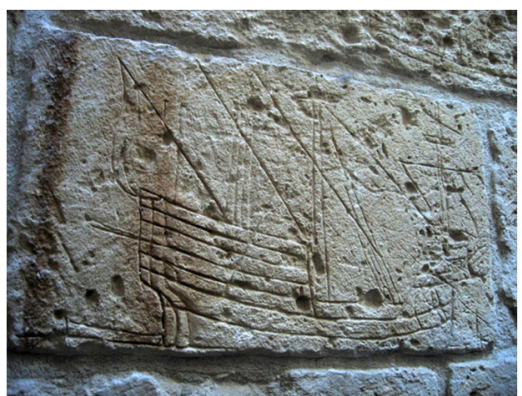

(a)

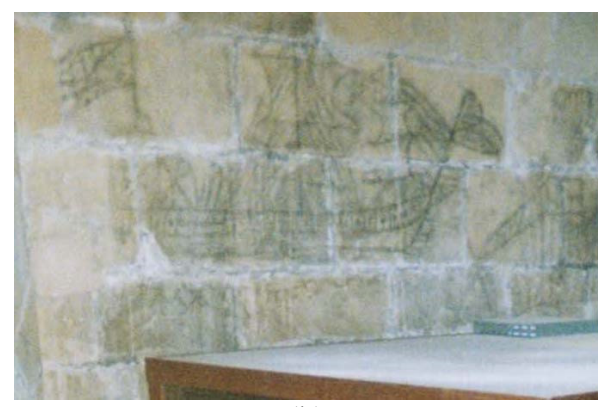

(b)

Figure 2: Monuments and sea: (a) a ship engraved in the ashlars of the Bonaire Cathedral in Cagliari, and (b) a similar drawing in the stone surface of the bell tower of Tarragona Cathedral (Spain).

remained strictly closed inside the walled perimeter and the coastal areas were reserved for the defence of the territory with the presence of forts and fortresses and costal towers. In 1742 fortifications reached the present dimensions. By the end of the 18th century, after the French Revolution, France tried to conquer Cagliari because of its strategic role in the Mediterranean, but the French were defeated by Sardinians. This was the latest reason for improving defensive districts along the coast, where St. Ignazio fort was built together with other smaller buildings.

However, this period was also very important for the growth of the city especially because many important public buildings appeared, such as the Theatre and Royal Palace. This was because sovereigns were resident in Cagliari from 1799 when Cagliari became the main city of the Savoy Kingdom now called Kingdom of Sardinia.

\subsection{Beach and leisure in the 'summer city'}

After the decommissioning of the military sites, new development of the city began, utilising the sea outside the walls as a cultural and economic resource. The zones close to the military urban walls were redesigned as urban gardens and wide avenues. Bastions were reused for different purposes e.g. the Monserrato Bastion [1] was converted into a hotel. Increasing commerce led to the reshaping of the old harbour and waterfront with the related buildings being redesigned after the demolition of the few remaining urban walls (figure 3 ). In this way, the image of the city changed together with the vocational aims of its community. The growth of the middle class required the construction of new entertainment venues such as cinemas, theatres, boulevards, bathhouses along the seaside and the building of a new quarter of small liberty houses close to the Poetto beach [2] (figure 4). The improvement of the salt sea extraction reshaped the coastal landscape. 


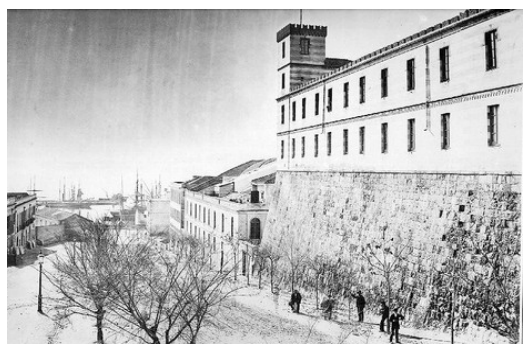

(a)

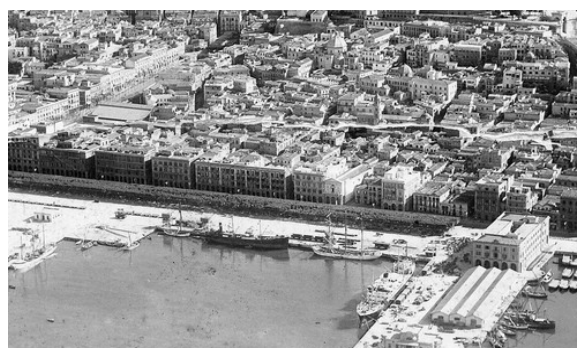

(b)

Figure 3: (a) The new hotel 'La scala di ferro' built on the old bastion of Monserrato (1877) and The Cerruti Theater (1859), later transformed in Politeama Cinema, and (b) the new waterfront and the redesigned harbour (1930) with the long line of apartment houses.
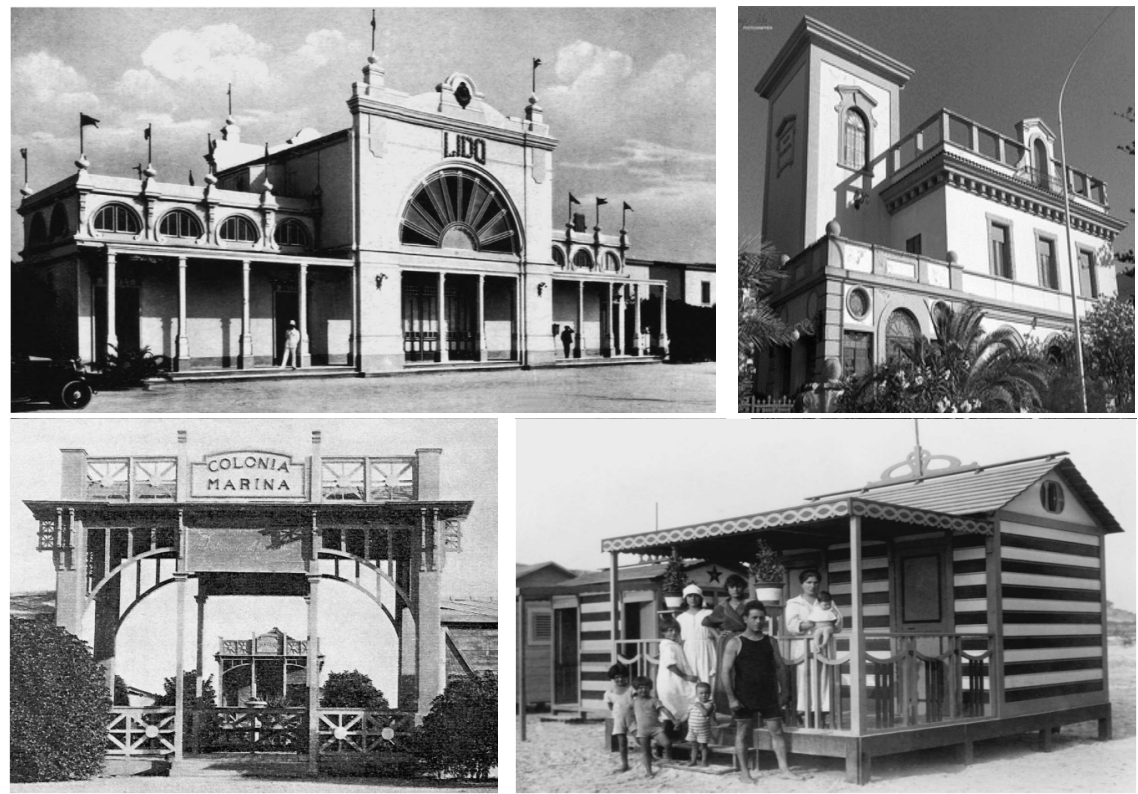

Figure 4: Bath houses, liberty houses and the traditional wooden cabinets called 'casotti' in the Poetto beach (1933-1934).

In 1937, the local architect Ubaldo Badas designed the 'Colonia Marina DVX' as a residence for pulmonary treatment. It was located on the beach close to the old Spanish coastal tower of Mezzaspiaggia and completed after the Second World War. It was later reused as a hospital but abandoned in 1982 to become a ruin [3] (figure 5). 


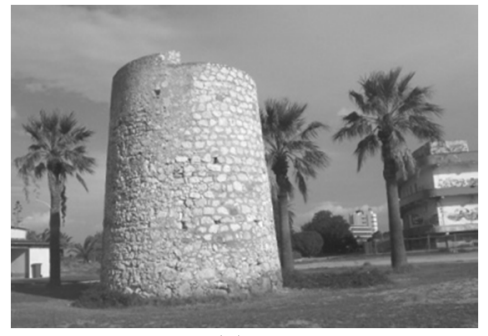

(a)

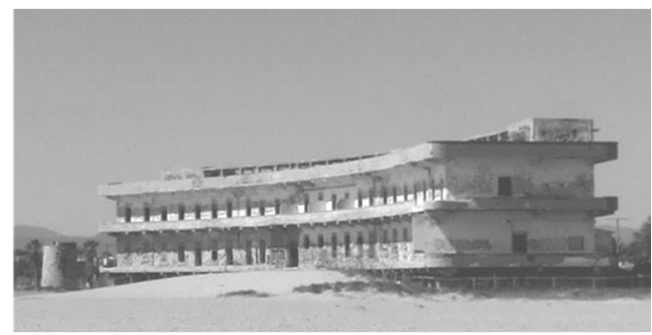

(b)

Figure 5: (a) The Mezzaspiaggia Spanish Coastal Tower and (b) the Marine Hospital in the Poetto beach.

\subsection{The touristic mission and the modern global city}

During the 1960s the symbol of the city was the Hotel Mediterraneo. This was the most luxurious hotel in the whole of Sardinia. It was built in front of the sea, outside the old town. In the same period, other hotels appeared in the coastal areas such as the 'Hotel Calamosca' (1958) and later the Hotel Panorama (figure 6).

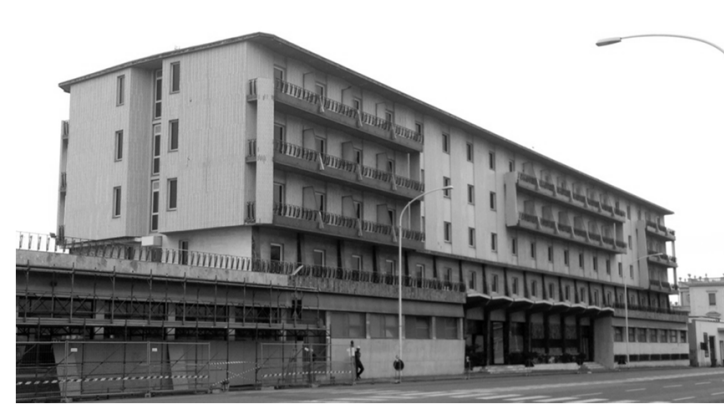

(a)

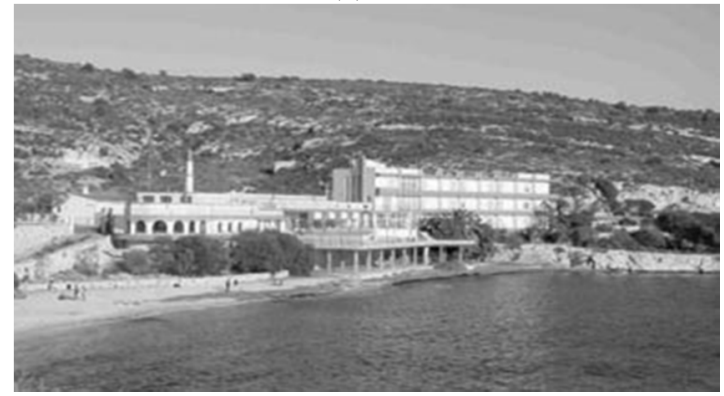

(c)

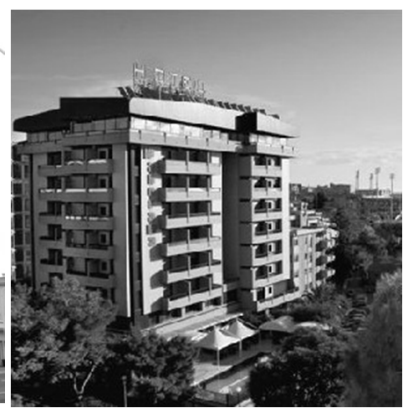

(b)

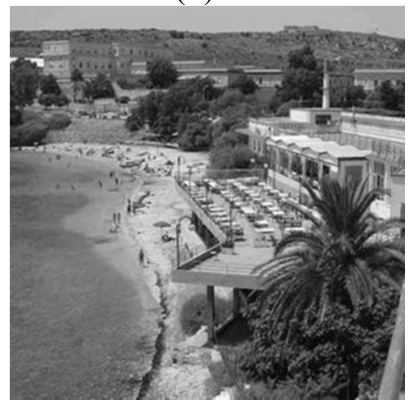

(d)

Figure 6: (a) The Mediterraneo Hotel; (b) the Panorama Hotel; (c) and (d) the Calamosca Hotel. 
Tourist development continued into the twenty first century with the appearance of large hotels, such as the T-hotel (used by international tours operators), the frequent conversion of residences into bed and breakfast, the building of the cruise terminal in 2008 and the design of the new sea boulevards such as that of 'Su Siccu' (figure 7).

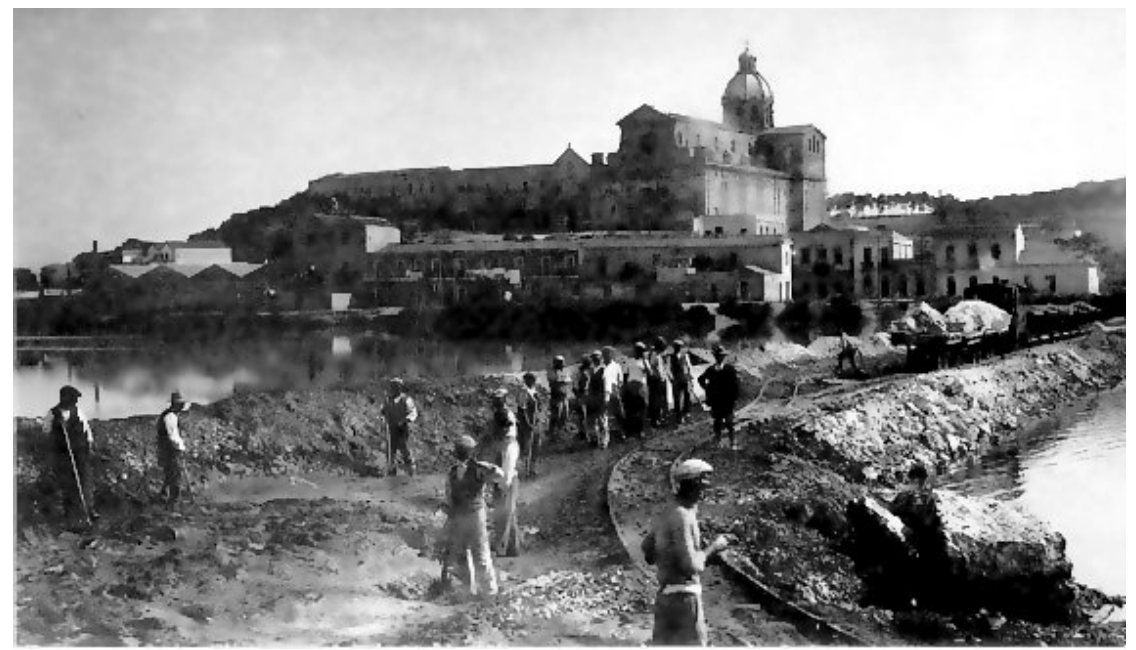

(a)

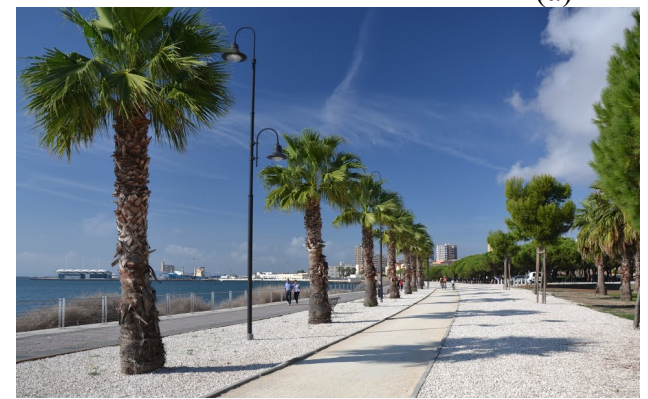

(b)

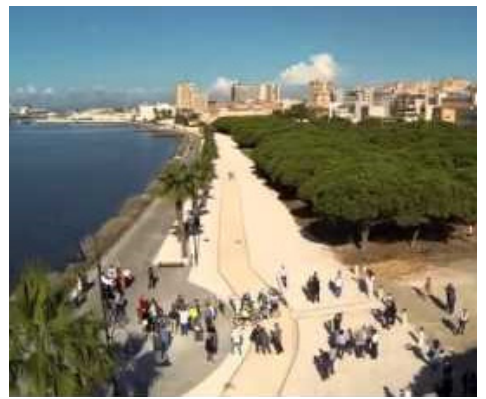

(c)

Figure 7: 'Su Siccu': (a) a picture (around 1930) of the marshy area and (b) and (c) the same area after the creation of the long boulevard with bicycle paths pedestrian areas in bright materials.

\section{Problems of conservation of the bright city}

\subsection{Stones and colours of the coastal city (SMG)}

Mediterranean cities are characterised by the colours of local stones from which they were built. The colours vary from white to ochre as is the case of Maltese, Lebanese, Greek, Syrian and Spanish settlements, as well as many of the Italian towns. 
The city of Cagliari is characterised by local limestones of different lithotypes, commonly known as 'pietra cantone', 'tramezzario' and 'pietra forte' which are historically quarried in the surroundings hills.

Clear differences distinguish these kind of stones [4]. Pietra cantone is a soft limestone marly arenaceous, with a pale cream-yellow colour. Its low physicalmechanical properties limited its use to walls refined with plaster; in fact, the damage of masonry is mainly caused by the loss of plaster and the elements of pietra cantone appear distressed by honeycomb and powdering. Tramezzario is a white bioclastic calcarenite that is harder and more durable than pietra cantone. It's mainly used as blocks for indoor masonries but also as decorative elements. Pietra forte is a white in colour, very compact organogenic reef limestone, harder than the others, more resistant to physical or chemical weathering. These excellent physical and mechanical properties mean it is often used in the most important historic city buildings in the shape of strong square blocks for architectural elements such as cantonal, buttresses, basements, portals, frames, columns and pilasters. Monuments are usually built with squared ashlars of 'pietra forte' as are the urban walls. However, rubble masonry in 'pietra cantone' is typical in residences or minor monuments that are to be plastered. Subordinate materials as granite and volcanic rocks, quarried in the isle were also used for specific purposes such as basements, street paving, wall wrapping, etc., while marble and travertine imported from other regions and countries was used mainly for ornamental purposes (figure 8).

Bricks were introduced during the Savoy period, while reinforced concrete widely appears from the beginning of the XX century and characterised the modern coastal development of the city. In the second half of the XX century the historical quarries closed, so that the buildings were mainly built with a white limestone known as 'Orosei marble' quarried in the Gulf of Orosei. This is also exported all over the world (China, Japan, USA).

\subsection{Weathering and degradation (SMG)}

The materials of coastal buildings suffer from normal weathering due mainly to natural sources such as sea salts, solar radiation, wind and biotic action [5]. Pollution is, in fact, a minor cause of degradation, because heavy industry never developed in the area and the few pollutant emissions produced are easily removed by wind action. The common forms of deterioration found in the area are formation of a superficial crust by reprecipitation of dissolved calcite, white and black crust of gypsum, efflorescence and sub-efflorescence, detachment, granular disintegration, alveolitazion, honeycomb (figure 9). However, most of the weathering damage is observed on the mortar and plaster of the buildings, mainly related to marine aerosols from diffusion and crystallization of soluble salts of marine origin especially in combination with direct solar radiation [6]. Insufficient cohesion and lack of adhesion are the most important weathering phenomena associated with mortars and are responsible for the weakness of the masonry.

Deterioration of the mortar can be a result of its original composition. Historical mortars in the city of Cagliari are lime mortars with siliclastic and carbonatic 


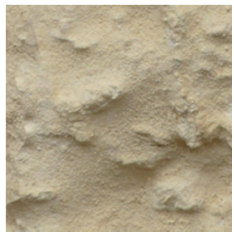

(a)

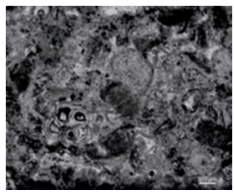

(b)

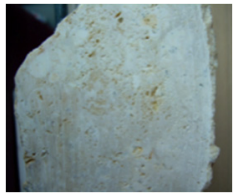

(c)

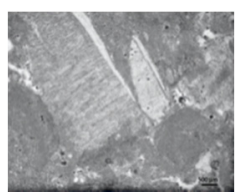

(d)

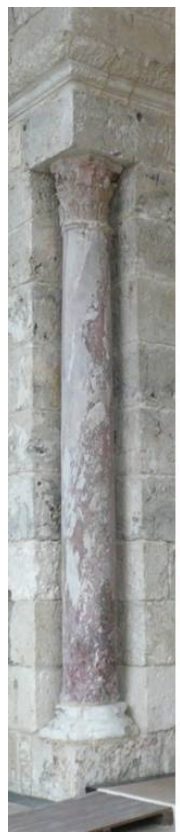

(e)

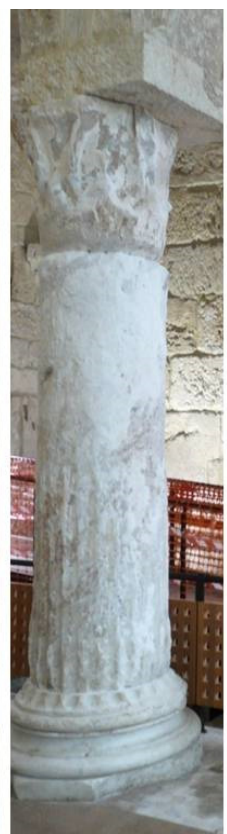

(f)
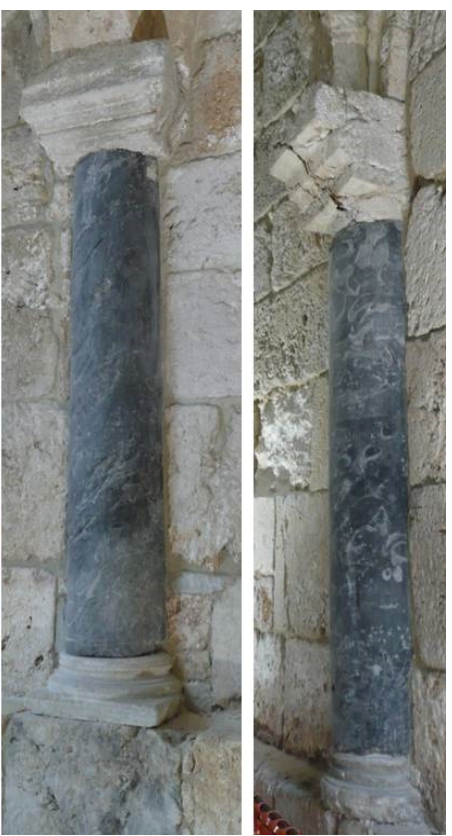

(g) (h)

Figure 8: Basilica of S. Saturnino: on the left (a)-(d), microphotographs of thin section of the sample of pietra cantone and pietra forte and on the right (e)-(h) typical marble used for monuments with degradation forms.

aggregates. Its physical properties (thermal expansion, colour, etc.) should ensure a high compatibility with the different elements in the old masonry structure made prevalently with pietra cantone. However, for the new restoration a hydraulic lime has been often used as cement or cement lime and these materials are also frequently responsible for an increased deterioration of the underlying masonry and lime mortar.

\subsection{Tourist anthropic aggression (DRF)}

Anthropic risks connected with tourism seems to be even more dangerous than the aggression caused by natural phenomena. The most relevant anthropic damage was undoubtedly caused by the bombing of the II World War, whose consequence are still evident in the urban context. Several ruins still exist in the old town: they represent urban degradation, but could also became great opportunities for the transformation and revitalization of the ancient quarters, creating new cultural attraction by means of their restoration and reuse. 

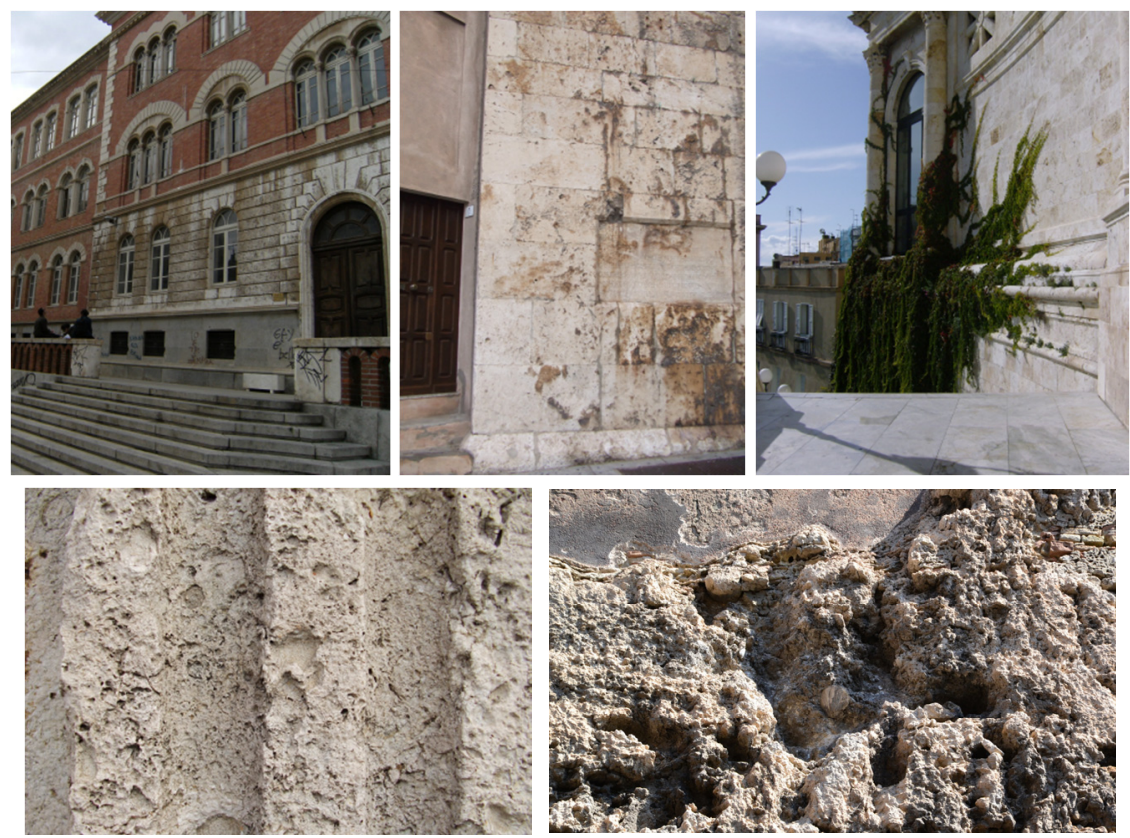

Figure 9: Weathering damage black crusts, biotic alteration, alveolization.

The pressure of tourism mean that the old quarters are particularly threatened by the transformation of traditional residences into hotels and bed and breakfasts (figure 10). Demolitions are inevitable but the conversions are not always respectful to the traditional building techniques and styles.
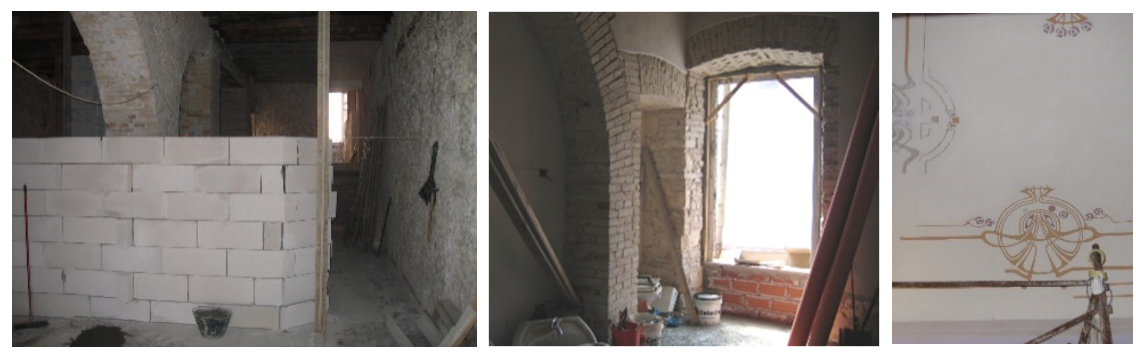

Figure 10: Worksite for the conversion of a traditional house into a bed and breakfast accommodation.

Another crucial point is the connection between the old and the modern city, as well as between the ancient quarters and the urban beach. Ancient urban walls are seen as cultural and tourist attractions, but also represent a barrier to urban connection. In recent years, some elevators were installed to overcome the significant difference in height between the higher and lower part of the city. The 
critical analysis of these elements highlights some technical and aesthetic problems that are very useful for a new debate on future solutions (figure 11).
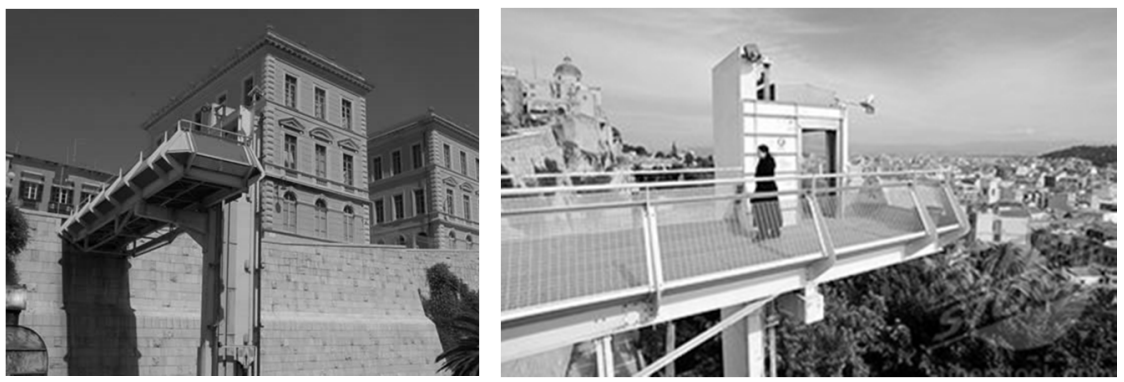

Figure 11: Lifts from the lower quarters to Castello.

In addition, the modern coastal city needs to be recognized as part of the urban cultural heritage and to be preserved from speculative aggression. Several buildings dating from the XX century are good witness to the coastal peculiarity of the city and have to be included into the list of national monuments.

\section{Protection and management of the coastal city (DRF)}

For the illustrated reasons, Cagliari needs to adopt innovative procedures for the monitoring of its monuments and of its coastal historical landscape.

Starting from the architectural scale, several recent buildings related to the modern coastal city have to be recognised as monuments and therefore restored and protected from demolition or unsympathetic redevelopment. The former bathhouses and historical hotels are examples of what could be included in this list.

The old town should be considered as the reference for the entire urban area, a worthy example of sustainability and for quality of life. However, it cannot remain as a separate world, so the historic centre and the modern town need to integrate in terms of cultural exchange, services and infrastructures. The relationship with the sea appears as a key-factor for the city development: the beach, the harbour and the salterns are historic elements of the old settlement.

Another issue is the possible reuse of a large number of redundant military and religious properties as public spaces and buildings.

In this time of economic crisis urban quality and cultural excellence of the public spaces is a strategic point - in some ways the most important one - for the development of a city of the third millennium.

For this reason, the University of Cagliari has set up an informative database system specifically for the study of cultural heritage vulnerability and for the planning and monitoring of transformations of historic sites. It is based on parametric assessment indexes, able to describe and neutrally compare different kind of degradation: physical, chemical and anthropic. The database can also store and analyse heterogeneous, and sometimes conflicting projects conceived for the 
urban area, in order to obtain a comparative strategic view of the set of the different actions already planned. This is essential awareness for every future strategy.

Recently, a national informative system produced by Italian Ministry for Cultural Heritage and Tourism (SICaR/web) has been tested. This may have use as an effective tool for monitoring plans and developments, even for WHL sites (figure 12) [5].
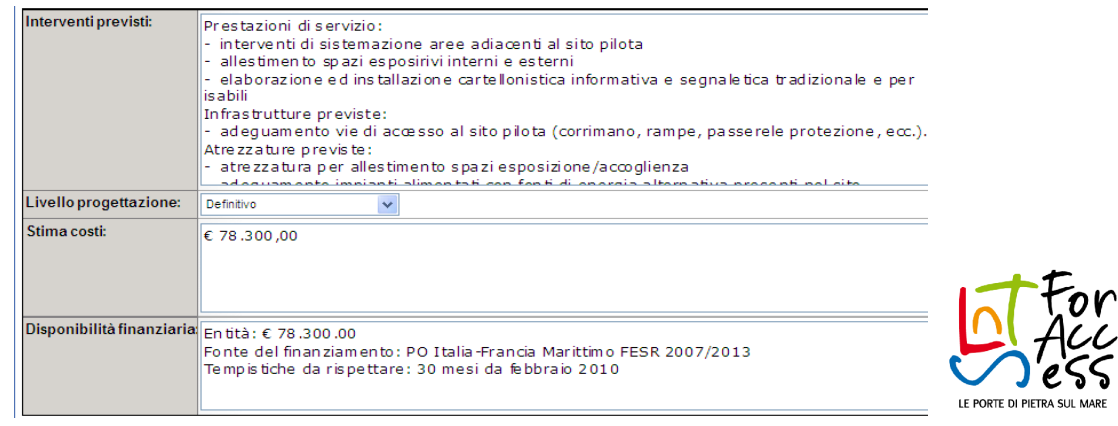

Figure 12: The datasheet for the monitoring of strategic projects tested on the Coastal Towers during the For-Access project.

\section{Conclusion}

This study highlights the importance of interdisciplinary researches for the knowledge and the protection of the coastal cities. In fact, their cultural heritage appears more threatened by the human activities than by the natural environment. The twin pressures of tourism and urban redevelopment are the most important set of problems to cope with.

The only solution comes from the deep knowledge of the historical and cultural relationship between the settlement and the sea and the way in which it has changed during centuries, in order to understand the new significance of the sea for the present city, including the old town and the modern developments.

In the case study of Cagliari great effort has to be make in monitoring the transformation of traditional residences into hotels - but also restaurants, shops and clubs - to fulfil the requirements of both tourism and modern urban life.

The support of the idea of Cagliari as a University City, instead of just a centre for commerce could be a key strategy for future development, in terms of sustainable transformation of the public real estate such as the military, railway and coastal properties.

In addition, the last point is the understanding and the new interpretation of the ancient concept of the coastal city as a 'door' for the inlands, giving value to the role of the coastal settlement as a hub - an intersection of places, cultures, histories and communities. 


\section{References}

[1] Fiorino, D.R., Stratigraphic evidence in the ancient urban walls of Cagliari (Sardinia-Italy), in C. Brebbia, C. Clark (eds), Defence Sites II. Heritage and Future, WIT Transactions on the Built Environment: Southampton, Vol. 143, pp. 257-268, 2014.

[2] Cao, G., La città estiva, Verbavolant: Cagliari, 1998.

[3] Cocco, G.B., Ubaldo Badas. La colonia marina Dux a Cagliari. Architettura e video, Gangemi: Roma, 2012.

[4] Giannattasio, C. \& Grillo, S.M., The Mezzaspiaggia tower (Cagliari-Italy): the dating of structures by the metrological-chronological analysis of masonry and the petro-geochemical stratigraphy of building materials, Proceedings of the 37th International Symposium on Archaeometry, eds Turbanti Memmi, I., Springer-Verlag: Berlin-Heidelberg, pp. 489-494, 2011.

[5] Siegesmund S. \& Snethlage R. (eds), Stone in Architecture Property, Durability, Springer Heidelberg Dordrecht: London-New York, 2011.

[6] Prokos, P., Equilibrium conditions of marine originated salt mixture: an ECOS application at archaeological site of Delos, Greece, Salt weathering on buildings and stone sculptures proceedings, The National Museum Copenhagen: Copenhagen, pp. 139-149, 2008.

[7] Fiorino, D.R., Tools for monitoring and managing historical buildings: the innovative use of the SICaR/web system, Arkos, July-December 2015, pp. 13$29,2015$. 